\title{
Expression of androgen-producing enzyme genes and testosterone concentration in Angus and Nellore heifers with high and low ovarian follicle count
}

\author{
Bárbara Loureiro $^{\mathrm{a}}$, Ronaldo L. Ereno ${ }^{\mathrm{b}}$, Mauricio G. Favoreto ${ }^{\mathrm{a}}$, \\ Ciro M. Barros ${ }^{\mathrm{b}, *}$ \\ ${ }^{a}$ Laboratory of Animal Reproductive Physiology, University of Vila Velha (UVV), Vila Velha, Espírito Santo, Brazil \\ ${ }^{\mathrm{b}}$ Department of Pharmacology, Institute of Biosciences, São Paulo State University (UNESP), Botucatu, São Paulo, Brazil
}

\section{A R T I C L E I N F O}

\section{Article history:}

Received 3 August 2015

Received in revised form 12 January 2016

Accepted 1 February 2016

\section{Keywords:}

Ovary

Follicle

Testosterone

Androgen enzymes

\begin{abstract}
A B S T R A C T
Follicle population is important when animals are used in assisted reproductive programs. Bos indicus animals have more follicles per follicular wave than Bos taurus animals. On the other hand, $B$ taurus animals present better fertility when compared with $B$ indicus animals. Androgens are positively related with the number of antral follicles; moreover, they increase growth factor expression in granulose cells and oocytes. Experimentation was designed to compare testosterone concentration in plasma, and follicular fluid and androgen enzymes mRNA expression (CYP11A1, CYP17A1, 3BHSD, and 17BHSD) in follicles from Angus and Nellore heifers. Heifers were assigned into two groups according to the number of follicles: low and high follicle count groups. Increased testosterone concentration was measured in both plasma and follicular fluid of Angus heifers. However, there was no difference within groups. Expression of CYP11A1 gene was higher in follicles from Angus heifers; however, there was no difference within groups. Expression of CYP17A1, $3 B H S D$, and $17 B H S D$ genes was higher in follicles from Nellore heifers, and expression of CYP17A1 and 3BHSD genes was also higher in HFC groups from both breeds. It was found that Nellore heifers have more antral follicles than Angus heifers. Testosterone concentration was higher in Angus heifers; this increase could be associated with the increased mRNA expression of CYP11A1. Increased expression of androgen-producing enzyme genes (CYP17A1, 3BHSD, and 17BHSD) was detected in Nellore heifers. It can be suggested that testosterone is acting through different mechanisms to increase follicle development in Nellore and improve fertility in Angus heifers.
\end{abstract}

(c) 2016 Elsevier Inc. All rights reserved.

\section{Introduction}

It is well known that Bos indicus and Bos taurus animals behave differently when referring to reproduction [1]. Taurine animals reach sexual maturity earlier [2,3] and have smaller calving intervals than indicine females [4]. Moreover, their estrus is more evident and last for more hours [5].

\footnotetext{
* Corresponding author. Tel.: +55 14 997765624; fax: +55 1438116253 . E-mail address: barrosciro@gmail.com (C.M. Barros).
}

On the other hand, $B$ indicus animals develop considerably more follicles per follicular wave than $B$ taurus animals [6,7]. This feature is especially important for animals that are used in assisted reproductive technologies such as superovulation, ovum pick-up, and in vitro embryo production.

The estrus cycle and follicular development are stimulated by hormones such as follicle-stimulating hormone (FSH), luteinizing hormones, and estrogen. Although in reduced concentrations, androgens are also important to promote follicular growth. They are synthesized by the thecal cells under the influence of luteinizing hormone 
through the enzymatic conversion of androgen precursors [8]. In the follicular fluid, androgens can act by increasing FSH actions, or serve as a substrate to the production of estradiol by aromatase [9].

In bovines, androgen concentrations are positively related with the number of antral follicles in the ovary [10]. Furthermore, treatment with androgens increased the expression of growth factors in granulosa cells and oocytes of monkeys [11] and mice [8,12]. In vitro, treatment of preantral follicles with androgen increased follicle development and decreased apoptosis [13]. In addition, culture of granulosa cells with testosterone decrease mRNA and protein levels of anti-Mullerian hormone, a hormone that is known to hinder follicle development [14].

The present study aimed to evaluate expression of androgen-producing enzyme genes in antral follicles collected from Angus and Nellore heifers with low and high ovarian follicle count and measure plasma and intrafollicular testosterone concentration in these animals.

\section{Materials and methods}

All reagents and media used were obtained from SigmaAldrich (St. Louis, MO, USA) unless stated otherwise. Animals were housed and cared for in accordance with the guidelines described by the ethics committee of the Universidade do Estado de São Paulo (Botucatu).

\subsection{Animal selection}

To pre-select the animals an ultrasound (US) examination (Mindray, 5-10 MHz, China) was performed in a random day of the estrus cycle in 100 Angus and 100 Nellore heifers. Only heifers that were cycling and did not have follicles greater than $5 \mathrm{~mm}$ were selected. In this first evaluation, the total number of follicles in both ovaries was counted and the mean follicle number was determined for each breed. These heifers were synchronized with two doses of PGF2 $\alpha 11$ days apart. Four days after the second PGF2 $\alpha$ (approximately 24 hours after follicle recruitment), a second US evaluation was performed to confirm the total number of follicles in each heifer. Considering the mean \pm standard deviation (SD) of the follicle population in each breed, the heifers were classified into two groups as follows: the low follicle count group (LFC; heifers that had the total number of follicles below the mean minus the SD) and high follicle count group (HFC; heifers that had the total number of follicles above the mean plus the SD). A total of 18 Nelore heifers were selected and allocated into two groups: eight with HFC ( $\geq 40$ follicles) and 10 with LHC ( $\leq 20$ follicles). For Angus heifers, 22 were selected and allocated into two groups: 13 with HFC ( $\geq 20$ follicles) and 09 with LFC ( $\leq 13$ follicles).

Heifers were kept in Brachiaria brizantha grass ad libitum, were fed $2 \mathrm{~kg}$ of Cynodon spp hay and $4 \mathrm{~kg}$ of concentrate (16\% crude protein and 70\% total digestible nutrients)/per animal/day during 90 days. After this adaptation period, all heifers were yet again synchronized using the same protocol (two doses of PGF2 $\alpha 11$ days apart). When heifers showed estrus, they were evaluated by US every 12 hours until ovulation. Twenty-four hours after ovulation, heifers were slaughtered in a local abattoir.

After slaughter, ovaries were collected and placed in a saline solution at $4{ }^{\circ} \mathrm{C}$ to be transported to the laboratory. Three follicles from 2 to $4 \mathrm{~mm}$ in diameter were dissected from the ovary contralateral to the corpus luteum. Follicles were frozen individually in 1-mL Qiazol from the RNeasy Microarray Tissue Mini kit (Qiagen, Valencia, CA, USA) at $-80^{\circ} \mathrm{C}$.

\subsection{Real-time polymerase chain reaction}

This experiment was designed to evaluate the mRNA expression of androgen-producing enzymes. Twenty-two Angus heifers (LFC $=09$ and HFC $=13$ ) and 18 Nellore heifers ( $L F C=10$ and HFC $=08$ ) were used in this experiment (these heifers were selected out of the 200 heifers US at the beginning). Total RNA was extracted individually from three follicles from each animal using the RNeasy Microarray Tissue Mini kit following the manufacturer's instructions. Follicles were homogenized with an UltraTurrax (IKA, Campinas, SP, Brazil) for 1 minute in $1 \mathrm{~mL}$ of QIAzol. Total extracted RNA was stored at $-80^{\circ} \mathrm{C}$ until realtime polymerase chain reaction analysis. RNA samples $(1 \mu \mathrm{g})$ were incubated with DNAse I ( $1 \mathrm{U} / \mu \mathrm{g}$; Invitrogen) and reverse transcribed with SuperScript III (Invitrogen) and oligo-dT primers.

Quantitative real-time polymerase chain reaction analysis of four androgen-producing enzyme genes (Cholesterol side chain cleavage enzyme [CYP11A1], 17-alpha-hydroxylase [CYP17A1], 3-beta-hydroxysteroid dehydrogenase [3BHSD], and 17-beta-hydroxysteroid dehydrogenase [17BHSD]) and a housekeeping gene (peptidylprolyl isomerase A; PPIA) was performed on each follicle. Specific primers (Table 1) were designed using Integrated DNA Technologies software (http://idtdna.com). To select the most stable housekeeping gene for detailed analysis of each cell type, PPIA, glyceraldehyde-3-phosphate dehydrogenase, and histone H2AFZ (H2AFZ) amplification profiles were compared using the geNorm applet for Microsoft Excel (http://genorm.cmgg.be) [15]. On the basis of this comparison, the relative quantification was performed with PPIA. Power SybrGreen PCR Master Mix (Applied Biosystems) reaction chemistry and the ABI Prism 7500 Sequence Detection System (Applied Biosystems) were used to quantify mRNA concentrations, and the specificity of each polymerase chain reaction product was determined through melting curve analysis. Negative controls (in which water replaced complementary DNA) were run in each plate. Duplicate reactions of each sample were analyzed. Target gene mRNA abundance is expressed relative to the level of PPIA mRNA. The relative expression of each gene was determined using the $\Delta \Delta \mathrm{Ct}$ method. Results are expressed as fold change $\left(2^{-\Delta \Delta C T}\right)$.

\subsection{Plasma and follicular fluid testosterone concentration}

Blood for the testosterone was drawn on the day of slaughter (24 hours after ovulation), centrifuged for 10 minutes at $900 \times \mathrm{g}$, and plasma was frozen at $-80^{\circ} \mathrm{C}$. The follicular fluid was collected from three 2 to $5 \mathrm{~mm}$ follicles 
Table 1

Primers sequences.

\begin{tabular}{|c|c|c|c|}
\hline Genes & Primer sequence $\left(5^{\prime}-3^{\prime}\right)$ & Amplicon size & $\begin{array}{l}\text { Annealing } \\
\text { temperature }\end{array}$ \\
\hline CYP11A1 & $\begin{array}{l}\mathrm{F}-\text { AGT CCA CAC CTC TTG CAC CTT TCT } \\
\mathrm{R}-\text { CGC CCA TCC CAT GAA GGC AAT AAA }\end{array}$ & $140 \mathrm{pb}$ & $59^{\circ} \mathrm{C}$ \\
\hline CYP17A1 & $\begin{array}{l}\mathrm{F}-\mathrm{GAA} \text { TGC CTT TGC CCT GTT CA } \\
\mathrm{R} \text {-CGC GTT TGA ACA CAA CCC TT }\end{array}$ & $330 \mathrm{pb}$ & $62{ }^{\circ} \mathrm{C}$ \\
\hline $3 B H S D$ & $\begin{array}{l}\text { F-GCC CAA CTC CTA CAG GGA GAT } \\
\text { R-TTC AGA GCC CAC CCA TTA GCT }\end{array}$ & $135 \mathrm{pb}$ & $59^{\circ} \mathrm{C}$ \\
\hline $17 B H S D$ & $\begin{array}{l}\mathrm{F} \text {-AGT CCA CAC CTC TTG CAC CTT TCT } \\
\mathrm{R}-\text { CGC CCA TCC CAT GAA GGC AAT AAA }\end{array}$ & $103 \mathrm{pb}$ & $58^{\circ} \mathrm{C}$ \\
\hline PPIA & $\begin{array}{l}\mathrm{F}-\mathrm{GCC} \text { ATG GAG CGC TTT GG } \\
\mathrm{R}-\mathrm{CCA} \text { CAG TCA GCA ATG GTG ATC T }\end{array}$ & $65 \mathrm{pb}$ & $60{ }^{\circ} \mathrm{C}$ \\
\hline
\end{tabular}

from the corpus luteum contralateral ovary. It was diluted $1: 100$ in the dilution buffer from the kit. Testosterone concentration was measured by an enzyme-linked immunosorbent assay (Uscn Life Science Inc., Wuhan, China), following manufacture's instruction, in 17 Angus heifers $($ LFC $=08$ and HFC $=09$ ) and 18 Nellore heifers (LFC $=10$ and $\mathrm{HFC}=08$ ). Plate reading was done using Biotech Wave HT Microplate Spectophotrometer (Bio Tek, Winooski, USA) with $450 \mathrm{~nm}$.

\subsection{Statistical analysis}

Gene expression was compared using the $\Delta \Delta \mathrm{Ct}$ values with the Proc Mixed procedure of SAS (SAS for Windows, version 9.2, Cary, NC, USA). An initial analysis to test the effect of follicle diameter on gene expression was performed. Because follicle diameter did not influence gene expression between Nelore and Angus or between HFC and LFC groups, a second analysis was performed with the mathematical model including two main effects (breed and follicle count) and all interactions with the animal as the subject and follicle as the repeated measure. Differences in individual mean values were analyzed through pair-wise comparisons (probability of difference analysis; SAS). Data on the testosterone plasma and intrafollicular concentration were analyzed by least-squares analysis of variance using the general linear models procedure of SAS. Testosterone concentration was log transformed before analysis. All values are reported as the least-squares mean \pm standard error of the mean. Differences were considered significant when $\mathrm{P}<0.05$, and values of $\mathrm{P} \geq 0.05$ and $\leq 0.1$ were taken to indicate a tendency.

\section{Results}

According to US analysis, Nellore heifers had more $(\mathrm{P}<0.05)$ follicles $(32 \pm 3.1)$ than Angus heifers $(20 \pm 2.6)$. LFC Nellore heifers had $16 \pm 1.54$ follicles, whereas HFC Nellore heifers had $52 \pm 1.70$ follicles. LFC Angus heifers had $10 \pm 1.41$, whereas HFC Angus heifers had $27 \pm 1.24$.

\subsection{Androgen-producing enzyme mRNA expression}

The results of the androgen-producing enzyme mRNA expression in follicles from Angus and Nellore heifers with LFC and HFC are expressed in the graphs as fold change normalized to one (Fig. 1). There was no effect of follicle size on mRNA expression in any of the genes studied.

The mRNA expression of CYP11A1, the side chain cleavage enzyme, was higher in follicles from Angus heifers when compared with follicles from Nellore heifers; however, no difference was found within groups or an interaction (Fig. 1A).

The mRNA expression of the enzymes CYP17A1, 3BHSD, and $17 B H S D$ was higher in follicles from Nellore heifers when compared with follicle dissected from Angus heifers (Fig. 1B-D). In addition, mRNA expression of CYP17A1 and $3 B H S D$ was higher in follicles from the HFC groups in both breeds (Fig. $1 \mathrm{~B}$ and $\mathrm{C}$ ). There was no interaction between breeds and groups.

\subsection{Plasma and intrafollicular testosterone concentration}

As listed in Table 2, plasma testosterone concentration was higher $(\mathrm{P}<0.001)$ in Angus heifers when compared with Nellore heifers. There was no difference between follicle count groups within breeds. Intrafollicular testosterone concentration was also higher in Angus animals $(\mathrm{P}<0.02)$ when compared with Nellore animals. There was no difference between follicle count groups within breeds.

\section{Discussion}

Androgens are important to promote follicle development. They are involved in the increased number of preantral and small antral follicles [16]. Furthermore, they affect the quality of the developing follicle and oocyte through the increase in the gene expression of important growth factors $[8,11,12]$.

In this study, we found that Nellore heifers have more antral follicles than Angus heifers. This trait is important when using biotechnologies such as superovulation and follicle aspiration for in vitro embryo production. The success of these technologies is dependent on the number and quality of oocytes collected.

Testosterone concentration was higher in Angus heifers, in both plasma and intrafollicular fluid. Expression of CYP11A1 gene was also higher in follicles from Angus heifers. This enzyme catalyzes the first step in the biosynthesis of all steroid hormones through oxidation of cholesterol [17]. However, there was no difference within low or high follicle heifers. 



Fig. 1. The mRNA expression (mRNA fold change, normalized to one) of androgen-producing enzymes CYP11A1, CYP17A1, 3BHSD, 17BHSD in follicles from Angus and Nellore heifers with low and high follicle count.

The mRNA expression of enzyme CYP17A1 (responsible for conversion of pregnenolone into dehydroepiandrosterone and androstenedione) and 3BHSD (involved in the conversion of $3 \beta$-hydroxysteroids, pregnenolone, $17 \alpha-$ hydroxypregnenolone, and dehidroepiandrosterone into 3-ketosteroids, progesterone, 17 $\alpha$-hydroxyprogesterone, and androstenedione, respectively) was higher in follicles dissected from Nellore heifers when compared with follicles from Angus heifers. In addition, in both breeds, follicles from HFC groups had higher mRNA expression of these enzymes when compared with follicles from the LFC group. The mRNA expression of $17 B H S D$, an enzyme that catalyzes the final step in the biosynthesis of testosterone, was also higher in follicles from Nellore heifers but not different within groups.

Even with a higher mRNA expression of three androgenconverting enzymes (CYP17A1, 3BHSD, and 17BHSD), Nellore heifers had lower concentrations of plasma and intrafollicular testosterone. It is possible that the increased
mRNA expression of CYP11A1, the first enzyme in the steroids pathway and the only one that was increased in Angus heifers in this study, is responsible for the increased plasma and intrafollicular concentration in testosterone seen in Angus heifers.

Androgens are important for follicle and oocyte quality. Female monkeys treated with androgen showed increased mRNA expression of FSH and IGF1 receptors and IGF1 in the granulose cells, and increased mRNA expression of IGF1 and IGF1 receptor in the oocyte [11]. Mice treated with androgens also showed increased mRNA expression of IGF1 receptor in oocytes of primordial follicles [12]. In addition, mRNA expression of GDF9 and TGFB was induced by androgens in granulose cells and oocytes [8]. These growth factors can improve quality and fertility capacity of the oocytes [18].

The higher testosterone concentration seen in this study might be responsible for the greater reproductive qualities reported for $B$ taurus animals. $B$ taurus and crossbred

Table 2

Number of animals in each breed and follicle count group (mean \pm SD), plasma and intrafollicular testosterone (testo) concentratrion (LS mean \pm SEM) analyzed by ELISA.

\begin{tabular}{|c|c|c|c|c|c|c|}
\hline \multirow[t]{2}{*}{ Variables } & \multicolumn{3}{|l|}{ Angus } & \multicolumn{3}{|l|}{ Nellore } \\
\hline & Total & LFC & HFC & Total & LFC & HFC \\
\hline Animals (n) & 17 & 08 & 09 & 18 & 10 & 08 \\
\hline Mean follicle & $20 \pm 2.6^{\mathrm{a}}$ & $10 \pm 1.41$ & $27 \pm 1.24$ & $32 \pm 3.1^{\mathrm{b}}$ & $16 \pm 1.54$ & $52 \pm 1.70$ \\
\hline Intrafollicular testo (ng/mL) & $46.08 \pm 4.6^{\mathrm{c}}$ & $42.95 \pm 7.4$ & $49.20 \pm 5.7$ & $29.25 \pm 4.8^{\mathrm{d}}$ & $22.77 \pm 6.4$ & $35.73 \pm 7.4$ \\
\hline Plasma testo $(\mathrm{ng} / \mathrm{mL})$ & $6.80 \pm 0.84^{\mathrm{e}}$ & $7.49 \pm 1.34$ & $6.10 \pm 1.02$ & $1.50 \pm 0.92^{\mathrm{f}}$ & $1.78 \pm 1.12$ & $1.22 \pm 1.45$ \\
\hline
\end{tabular}

Different letters in the same line indicate significant differences.

Abbreviations: HFC, high follicle count; LFC, low follicle count; LS, least squares; SD, standard deviation; SEM, standard error of the mean. 
taurus $\times$ indicus animals usually present younger age at puberty, longer estrus duration, shorter calving interval, and better pregnancy rates when compared with pure $B$ indicus animals $[1,4]$.

On the other hand, Nellore heifers presented greater follicle numbers. Androgens have been previously associated with pre-antral and antral follicle growth [10]. Treatment of female monkeys with androgens increased the number of pre-antral follicles and small antral follicles through androgens receptors [16]. Mossa et al. [10] also showed that mRNA expressions of CYP17A1 were higher in HFC animals. However, in their study, androstenedione concentration in the follicular fluid and testosterone concentration in the plasma were higher in HFC cows, although we found no difference between groups within breeds. It is worth mentioning that study by Mossa et al. used only crossbred Hereford $\times$ Angus $\times$ Charolais animals. Furthermore, it has been shown in women that testosterone concentration is directly related to the follicle sensitivity to FSH [19].

We concluded that Nellore heifers have more antral follicles than Angus heifers, and that in both breeds heifers can be classified in LFC or HFC groups. Moreover, Nellore heifers have increased mRNA expression of androgenproducing enzymes (CYP17A1, 3BHSD, and 17BHSD), with CYP17A1 and 3BHSD also higher in HFC heifers. On the other hand, testosterone concentration was higher in Angus heifers; this increase can be associated with the increased expression of CYP11A1. It could be suggested that testosterone is acting through different mechanisms to increase follicle development in Nellore and improve fertility in Angus heifers.

\section{Acknowledgments}

This work was supported by FAPESP grant number 2011/ 50964-0. B.L., R.L.E., and M.G.F. were granted a FAPESP scholarship.

Author contributions: All authors contributed equally to the design of the experiments and performance of the assays. B.L. wrote the article.

\section{Competing Interests}

None of the authors have any conflict of interest to declare.

\section{References}

[1] Randel RD. Reproduction of Bos indicus breeds and crosses. In: Proceedings, applied reproductive strategies in beef cattle. Texas A\&M University, College Station; 2005. p. 104-24.
[2] Patterson DJ, Corah LR, Brethour JR, Spire MF, Higgins JJ, Kiracofe GH, et al. Evaluation of reproductive traits in Bos taurus and Bos indicus crossbred heifers: effects of postweaning energy manipulation. J Anim Sci 1991;69:2349-61.

[3] Lammoglia MA, Bellows RA, Grings EE, Bergman JW, Bellows SE, Short RE, et al. Effects of dietary fat and sire breed on puberty, weight, and reproductive traits of F1 beef heifers. J Anim Sci 2000; $78: 2244-52$.

[4] Luna-Nevarez P, Rincon G, Medrano JF, Riley DG, Chase CC, Coleman SW, et al. Single nucleotide polymorphisms in the growth hormone-insulin-like growth factor axis in straightbred and crossbred Angus, Brahman, and Romosinuano heifers: population genetic analyses and association of genotypes with reproductive phenotypes. J Anim Sci 2011;89:926-34.

[5] Rhodes III RC, Randel RD. Reproductive studies of Brahman cattle. I. Behavioral effect of various dose levels of estradiol-17ß upon ovariectomized Brahman, Brahman x Hereford and Hereford cows. Theriogenology 1978;9:429-35.

[6] Segerson EC, Hansen TR, Libby DW, Randel RD, Getz WR. Ovarian and uterine morphology and function in Angus and Brahman cows. J Anim Sci 1984;59:1026-46.

[7] Carvalho JBP, Carvalho NAT, Reis EL, Nichi M, Souza AH, Baruselli PS Effect of early luteolysis in progesterone-based timed AI protocols in Bos indicus, Bos indicus x Bos Taurus, and Bos taurus heifers. Theriogenology 2008;69:167-75.

[8] Hickey TE, Marrocco DL, Amato F, Ritter LJ, Norman RJ, Gilchrist RB, et al. Androgens augment the mitogenic effects of oocyte-secreted factors and growth differentiation factor 9 on porcine granulosa cells. Biol Reprod 2005;73:825-32.

[9] Taniguchi F, Couse JF, Rodriguez KF, Emmen JM, Poirier D, Korach KS. Estrogen receptor-alpha mediates an intraovarian negative feedback loop on thecal cell steroidogenesis via modulation of Cyp17a1 (cytochrome P450, steroid 17alpha-hydroxylase/ 17,20 lyase) expression. FASEB J 2007;21:586-95.

[10] Mossa F, Jimenez-Krassel F, Folger JK, Ireland JL, Smith GW, Lonergan P, et al. Evidence that high variation in antral follicle count during follicular waves is linked to alterations in ovarian androgen production in cattle. Reproduction 2010;140:713-20.

[11] Dumesic DA, Abbott DH. Implications of polycystic ovary syndrome on oocyte development. Semin Reprod Med 2008;26: 53-61.

[12] Vendola K, Zhou J, Wang J, Famuyiwa OA, Bievre M, Bondy CA. Androgens promote oocyte insulin-like growth factor I expression and initiation of follicle development in the primate ovary. Biol Reprod 1999;61:353-7.

[13] Murray AA, Gosden RG, Allison V, Spears N. Effect of androgens on the development of mouse follicles growing in vitro. J Reprod Fertil 1998;113:27-33.

[14] Crisosto N, Sir-Petermann T, Greiner M, Maliqueo M, Moreno M, Aedo $\mathrm{P}$, et al. Regulation of ovarian follicular dynamics in farm animals. Implications for manipulation of reproduction. Theriogenology 2001;55:1211-39.

[15] Ramakers C, Ruijter JM, Deprez RH, Moorman AF. Assumption-free analysis of quantitative real-time polymerase chain reaction (PCR) data. Neurosci Lett 2003;339:62-6.

[16] McGee EA, Hsueh AJ. Initial and cyclic recruitment of ovarian follicles. Endocr Rev 2000;21:200-14.

[17] Payne AH, Hales DB. Overview of steroidogenic enzymes in the pathway from cholesterol to active steroid hormones. Endocr Rev 2004;25:947-70.

[18] Bonilla AQ, Oliveira LJ, Ozawa M, Newsom EM, Lucy MC, Hansen PJ. Developmental changes in thermoprotective actions of insulin-like growth factor-1 on the preimplantation bovine embryo. Mol Cell Endocrinol 2011;332:170-9.

[19] Barbieri RL. A renaissance in reproductive endocrinology and infertility. Fertil Steril 2005;84:576-7. 